\title{
BYZANTINE THEME OF CHIOS
}

\author{
Anton S. Mokhov \\ Ural Federal University, Ekaterinburg, Russian Federation
}

\begin{abstract}
The article is devoted to the study of the Byzantine theme system in the 10th - 11th centuries. The author believes that the reign of Basil II (976-1025) was marked by the mikra themata in Balkans and on Aegean Sea islands. They were in need of effective border defense. Theme of Chios was one of the mikra militaryadministrative districts, which were created in this period. The author detected five leaders of the theme in accordance with the historical sources: protospatharios and strategos Theodoros Beriboes; protospatharios, tagmatophylax and strategos Leon Karikes; protospatharios, tagmatophylax and strategos Bardas Mersiniotes; vestarches and strategos Ioannes Aristenos; vestes and strategos Michael Maurikas. The analysis of the sigillographic data led to the conclusion that the regular tagmata were the base of the military force of theme of Chios. Moreover, the fortress of Volissos was located in the northwest of Chios. The area around the fortress was inhabited by representatives of one ethnic group. They were under the leadership of doux, which was subordinate to the strategos of the theme. The famous officials of the civil administration of Chios included fiscal clerks - dioiketes, horreiarios and judicial clerks - krites of the velon. Theme of Chios had existed for about one hundred years. It was liquidated during the war between Byzantine and Tzachas, Turkish amir of Smyrna.
\end{abstract}

Key words: Byzantium, Byzantine army, Basil II, Chios, military reform, mikra themata, sigillography.

УДК 94(495).02+736.3

Дата поступления статьи: 17.08.2016

ББК Т3(0)4-9 Дата принятия статьи: 16.09.2016

\section{ВИЗАНТИЙСКАЯ ФЕМА ХИОС ${ }^{1}$}

\author{
Антон Сергеевич Мохов \\ Уральский федеральный университет, Екатеринбург, Российская Федерация
}

\begin{abstract}
Аннотация. Статья посвящена изучению византийской фемной системы в X-XI веках. По мнению автора, в правление Василия II (976-1025) на Балканах и на островах Эгейского моря создавались малые фемы. Они были необходимы для эффективной обороны границ. Одной из малых военно-административных единиц, созданных в это время, являлась фема Хиос. Автором установлено, что в источниках упоминаются пять правителей фемы: протоспафарий и стратиг Феодор Веривой; протоспафарий, тагматофилак и стратиг Лев Карики; протоспафарий, тагматофилак и стратиг Варда Мерсиниот; вестарх и стратиг Иоанн Аристин; вест и стратиг Михаил Маврики. Сфрагистические данные позволяют утверждать, что основой военных сил фемы Хиос являлись регулярные тагмы. Кроме этого, на северо-востоке Хиоса находилась крепость Волисcoc. Территория вокруг нее была населена представителями одной этнической группы. Жители этого района находились под руководством дуки, который подчинялся стратигу фемы. Из должностных лиц гражданской администрации на Хиосе известны чиновники налогового ведомства (диикиты, ориарии), а также судья вила. Фема Хиос существовала около 100 лет и была ликвидирована во время войны между Византией и турецким эмиром Смирны Чаканом.

Ключевые слова: Византия, византийская армия, Василий II, Хиос, военная реформа, малые фемы, сфрагистика.
\end{abstract}

В современной историографии, посвященной истории Византии IX-XI вв., значитель(2) ное внимание уделяется изучению военно-ад- министративной системы империи. Данное направление отличается большим разнообразием изучаемых проблем. В работах отече- 
ственных и зарубежных византинистов рассматриваются вопросы, связанные с историей отдельных фем, контингентов императорской армии и военного флота, различных командных должностей. В последние годы весьма активно проводятся исследования микроструктурных компонентов византийской военной системы (турмы, клисуры, малые фемы и пр.). Этому в значительной степени способствует публикация новых сфрагистических и эпиграфических источников.

Данная статья посвящена истории фемы Хиос, одной их малых византийских фем, созданных в правление Василия II (976-1025). Следует отметить, что небольшие военно-административные единицы начали создаваться на Балканах при Иоанне I Цимисхии (969976). В «Эскуриальском тактиконе» упоминаются фемы Веррия, Стримон, Другубица, Иоаннополь, Эдесса [22, p. 267-268, 355-363]. $\mathrm{B}$ последней четверти $\mathrm{X}$ - первой четверти XI в. $\mu 1 к \rho \grave{\alpha} \theta \varepsilon ́ \mu \alpha \tau \alpha$ были созданы в Сервии, Лариссе, Аркадиополе, Филиппополе, Дристpe. Они являлись микроструктурными, то есть не подлежащими разделению на более мелкие административные единицы, компонентами византийской фемной системы. Как правило, административный центр малой фемы

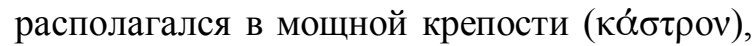
которая защищала стратегически важные дороги, порты, горные перевалы, переправы через реки. Военные контингенты $\mu$ коф $\theta \dot{\varepsilon} \mu \alpha \tau \alpha$ состояли из постоянного гарнизона крепости, а также отрядов местных стратиотов, которые выполняли вспомогательные функции [3, c. 26-30].

Опыт, приобретенный в ходе реформирования провинциальных военных структур на Балканах, был использован в других регионах империи - в Южной Италии, Таврике, на островах Эгейского моря. Следует отметить, что для Восточного Средиземноморья проблема реорганизации военно-административной системы была особенно актуальной. Прежде всего, это было продиктовано возвращением под власть Византии больших густонаселенных островов Крит и Кипр. В свою очередь, усиление позиций империи в данном регионе привело к обострению отношений с мусульманскими государствами Ближнего Востока и Северной Африки. С 970-х гг. число арабс- ких нападений на острова Додеканеса, побережье Греции и Малой Азии значительно возрастает. Для организации эффективной обороны в дополнение к уже существующим фемам Самос, Кивирреотов и Эгейского моря, были созданы фемы Крит, Кипр, Кикладские острова, Керкира, Навпакт, Авидос, Боспор и Хиос [7, p. 120-122].

Остров Хиос (Хíos), расположенный в восточной части Эгейского моря у побережья Малой Азии, с античных времен являлся важным центром сельскохозяйственного производства и международной торговли. Главным богатством Хиоса считалась смола мастикового дерева (Pistacia lentiscus), которая использовалась для приготовления лекарственных средств и парфюмерии. Мастика $(\mu \alpha \sigma \tau i ́ \chi \alpha)$ высоко ценилась на средиземноморских рынках. Начиная с эдикта Диоклетиана 301 г. торговля ароматическими смолами, содержащими мастику, как и многими другими редкими минеральными и растительными веществами, регулировалась государством. Кроме этого, на Хиосе добывали весьма ценный розовый мрамор (portasanta), который использовался как в монументальном строительстве, так и в прикладном искусстве [11, p. 261, 271-272, 288; 16, S. 143-144; 20, p. 388-389].

В период поздней Римской империи Хиос входил в состав провинции Insulae. В данное время военное значение острова было невелико и ограничивалось участием в снабжении армии. В 536 г. по распоряжению Юстиниана I (527-565) была создана quaestura exercitus. Квестору армии были подчинены пять провинций: Moesia Inferior, Scythia Minor, Cyprus, Caria, Insulae. Задача нового ведомства состояла в полноценном и своевременном снабжении византийской армии на дунайской границе, в Нижней Мезии и Малой Скифии. Необходимые для войск ресурсы доставлялись по морю из малоазийской провинции Кария, а также с островов Кипр, Родос, Кос, Самос, Хиос. Известно также, что после потери Византией контроля над северо-восточной частью Балкан флот quaestura exercitus продолжал находиться в Эгейском море [15, p. 280, 482-483].

Со второй половины VII в. на Средиземном море началось столкновения между Византией и арабами. Империя оказалась в чрез- 


\section{ВОЙНА И ВИЗАНТИЙСКОЕ ОБЩЕСТВО}

вычайно сложном положении, так как помимо обороны побережья Малой Азии и Греции ее военно-морским силам приходилось отражать грабительские набеги мусульман на острова. В 670-е гг. на основе сил упраздненной quaestura exercitus был создан регулярный

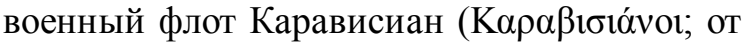

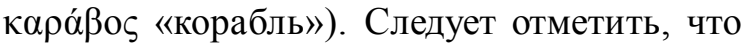
данная военная структура оказалась малоэффективной. При императорах Исаврийской ди-

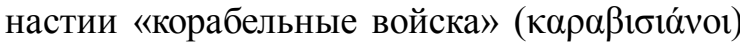
были расформированы, а вместо них созданы морские фемы Кивирреотов и Эгейского моря [7, p. 77-85].

Несмотря на неоднократные преобразования военно-морских сил империи, в источниках не сохранилось сведений о создании на Хиосе каких-либо постоянных военных структур. По всей видимости, на восточном и северо-западном побережье острова в VIIVIII вв. располагались временные стоянки кораблей императорского флота, которые были необходимы для пополнения запасов пресной воды и продовольствия [26, p. 265]. Археологические исследования, которые проводились в юго-восточной части Хиоса, позволили установить, что в 610-668 гг. на территории при-

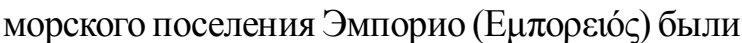
возведены каменные укрепления. Однако к концу VII в. крепостные стены оказалось разрушенными и в последующее время не восстанавливались. Более того, многие сельские поселения на юге Хиоса были покинуты. Опасаясь арабских нападений, местные жители переселялись в более защищенные районы на восточном побережье острова [13, p. $80-81$; 16, S. 160-161].

Во второй половине VII - IX в. императорская администрация на Хиосе была представлена только гражданскими чиновниками. В частности, Г. Закосом и А. Веглери была опубликована печать Георгия, скривона и главного коммеркиария апотеки Асии, Хиоса и Лесбоса

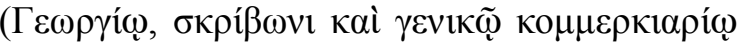

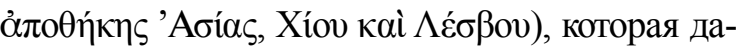
тируется 690/691 г. [30, p. 249, no. 168]. Этот моливдовул свидетельствует, что в конце VII в. Хиос продолжал оставаться значимым центром торговли, связанным с Константинополем, западным побережьем Малой Азии и крупными островами Эгейского моря. Упомянем также печать IX в., принадлежавшую диикиту Само-

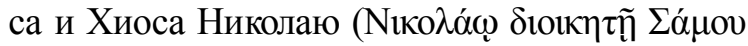
кaì $\tau \tilde{\eta}_{\varsigma}$ Xíov) [30, p. 1222, no. 2216].

Специально следует упомянуть о печатях архонтов Хиоса. Опубликовано три моливдовула, владельцами которых являлись эти должностные лица. Наиболее ранней из них является печать Георгия, императорского ку-

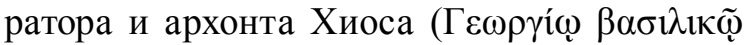

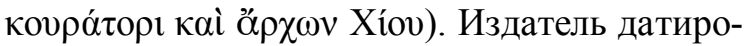
вал моливдовул VIII-IX веками. По нашему мнению, существование на Хиосе императорской куратории в VIII-IX вв. вызывает серьезные сомнения. Г. Шлюмберже писал, что сведения об этой печати он получил от французского коллекционера А. Сорлен-Дориньи [28, p. 196, nо. 3]. Изображение буллы отсутствует, ее местонахождение в настоящее время неизвестно. Эти причины позволяют поставить под сомнение правильность прочтения легенды. Не исключено, что после имени владельца печати был указан его титул (на-

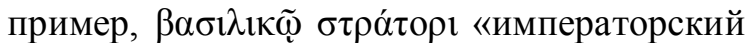
стратор»), а не должность - $\beta \alpha \sigma \imath \lambda \imath \kappa \tilde{\omega}$

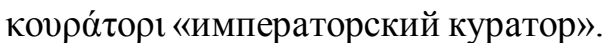

Две печати архонтов Хиоса датируются второй половиной IX - первой половиной $\mathrm{X}$ века. Речь идет об анонимной булле императорского кандидата и архонта Хиоса $(\beta \alpha \sigma \imath \lambda \iota к \tilde{\omega}$

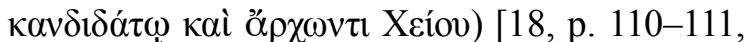
no. 204], а также моливдовуле Георгия, императорского спафарокандидата и архонта Хио-

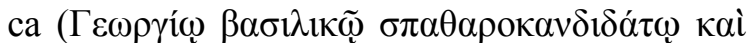
ö $\rho \chi \omega v \tau \imath \tau \tilde{\eta} \varsigma$ Xíov) [9, p. 123-124, no. 41.1].

По мнению Э. Маламут, Хиос, как и некоторые другие острова Эгейского моря, находился под властью «муниципальных архонтов». Это были представители знатных семей, проживавших в главном портовом поселении острова. До второй половины X в. архонтии островов не входили в состав фем, представляя особую форму административной организации [20, p. 300-301]. По нашему мнению, данная точка зрения является неверной, так как она противоречит современным представлениям о военной системе империи. Следует учитывать, что в Византии VIII-IX вв. не могло быть никаких «муниципальных» военных контингентов, только фемные. Поэтому архонты Хиоса были подчинены друнгарию

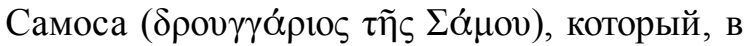


свою очередь, находился под началом стра-

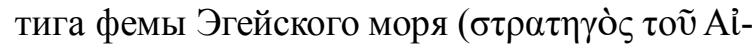

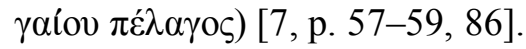

В IX - начале X в. Хиос неоднократно подвергался арабским нападениям [12, S. 207, 258-261]. Однако в источниках не сохранилось сведений о мерах, предпринятых властями для укрепления обороны острова. Как и в предыдущий период, Хиос не являлся местом постоянного размещения сил императорского флота. По мнению Дж. Прайора, в первой половине X в. на Хиосе располагалась аплекта

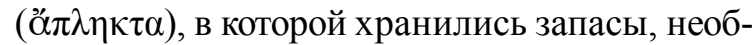
ходимые для организации морских экспедиций против арабов [26, p. 265]. Отметим, что данная точка зрения не подтверждается сведениями источников. Местом сбора византийского флота во время походов против «богоненавистного Крита» в 911 и 960 гг. были порты на малоазийском побережье. Прежде всего, речь идет о приморской крепости Фигел-

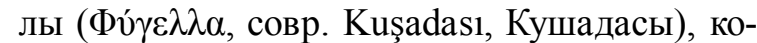
торая находилась в 15 км юго-западнее Эфеca $[10$, p. 20, n. 46].

Таким образом, вплоть до правления Василия II Хиос не играл значимой роли в военно-административной системе империи. Более того, остров почти не упоминается в исторических хрониках. Например, в «Обозрении истории» Иоанна Скилицы Хиос упомянут только три раза, причем дважды как место ссылки государственных преступников. В 970 г. в «вечное заключение» на остров, вместе с женой и детьми, был отправлен патрикий Варда Фока, предводитель неудачного мятежа против Иоанна Цимисхия. Однако в 977 г. Фоку освободили и назначили командовать войсками, отправленными для подавления восстания магистра Варды Склира [14, р. 294.88-91, 324.34-38]. В 1042 г., сразу после вступления на престол, Константин IX Мономах распорядился сослать на Хиос свергнутого императора Михаила V [14, p. 423.54-56].

Одним из наиболее важных направлений военной политики Василия II являлось изменение способа комплектования византийской армии. В течение длительного времени происходила замена малоэффективных фемных стратиотских ополчений на регулярные воинские формирования (тагмы, таксиархии и пр.). В ито- ге в полевой армии и провинциальных военных контингентах стали преобладать хорошо обученные, вооруженные и мотивированные регулярные войска. Смена способа комплектования, в свою очередь, привела к значительным изменениям в стратегии и тактике. Отныне на второстепенных направлениях императорская армия старалась вести преимущественно оборонительные действия. Сухопутные рубежи Византии обороняли регулярные отряды, размещенные на постоянной основе в пограничных крепостях [2, с. 26-29]. На морском побережье и на островах происходили аналогичные процессы. В отличие от предыдущего периода, когда противостоять нападениям противника должен был военный флот, в конце X - начале XI в. эту задачу стали выполнять сухопутные войска. Судя по свидетельствам источников, после высадки на берег арабские пираты были неспособны противостоять регулярным византийским отрядам. В этот период мусульмане потерпели ряд тяжелых поражений на побережье Фракисия и Греции, а также на островах Эгейского моря. Нападавшие несли тяжелые потери, попадали в плен, византийские войска захватывали их корабли и ранее награбленную добычу. Исключением являлась Южная Италия, где у арабов было подавляющее численное превосходство [12, p. 370-374].

Данные археологических исследований свидетельствуют, что в последней четверти $\mathrm{X}$ в. на островах Додеканеса и эгейском побережье Малой Азии началась реконструкция старых и возведение новых оборонительных сооружений. Отметим также, что результаты археологических раскопок подтверждаются данными эпиграфики. В качестве примера можно привести надпись протоспафария и таг-

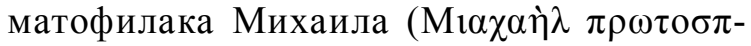

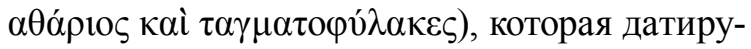
ется 988 годом. Она была обнаружена во вре-

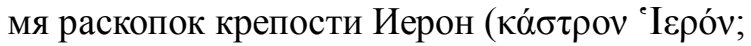
совр. Didim, $\Delta$ í $v \mu \alpha)$ [19, p. 202-203]. На Хиосе начало изменений в военной сфере также прослеживается по археологическим и эпиграфическим данным. В последней четверти $\mathrm{X}$ в. на восточном берегу острова была построена крепость Хиос. В расположенной внутри оборонительных стен церкви св. Георгия была обнаружена надпись, которая позволяет установить, что основные строительные ра- 


\section{ВОЙНА И ВИЗАНТИЙСКОЕ ОБЩЕСТВО}

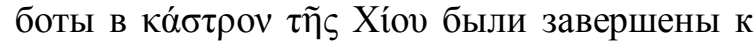
993 г. [16, S. 152; 20, p. 236].

Стратиг Хиоса впервые упоминается в источниках в 1025/1026 г. в связи с нападением арабов на Кикладские острова. Иоанн Скилица писал, что стратиг Самоса Георгий Фео-

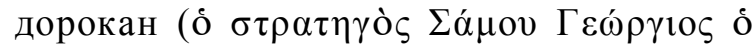

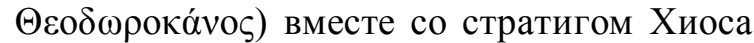

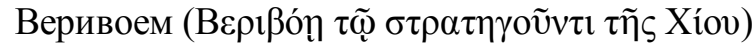
вступили с ними в бой и одержали победу. Они захватили 12 полностью оборудованных кораблей вместе с командами, а остальных обратили в бегство [14, p. 373.11-14].

В письменных источниках Веривой больше не упоминается. Предположительно ему принадлежали печати: Феодора Веривоя, протоспафария и стратига $(\Theta \varepsilon о \delta \omega \rho \omega \pi \rho \omega \tau о \sigma \pi \alpha \theta \alpha \rho i ́ \omega$

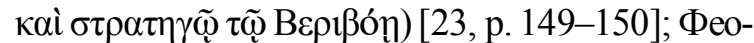
дора Веривоя, протоспафария и стратига Ларис-

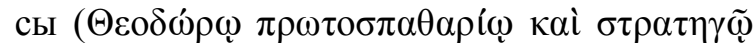

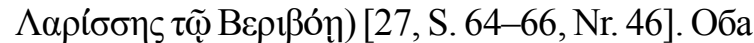
модивдовула датируются второй четвертью XI века.

По данным сфрагистики, известны еще четверо стратигов Хиоса:

1. Лев Карики, протоспафарий, тагмато-

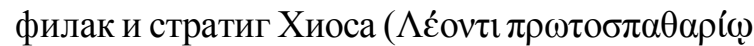

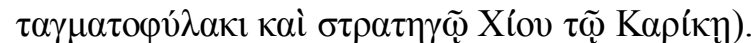
Впервые печать была опубликована Г. Шлюмберже, который неверно прочел патроним и титул владельца: «Лев Кипариссиот, спафарий» $[28$, p. 196, nо. 2]. Корректируя прочтение надписи, В. Зайбт датировал моливдовул второй половиной XI в. [29, S. 219, Nr. 4].

2. Варда Мерсиниот, протоспафарий, тагматофилак и стратиг Хиоса (В $\alpha \delta \alpha$ $\pi \rho \omega \tau о \sigma \pi \alpha \theta \alpha \rho i ́ \omega, \tau \alpha \gamma \mu \alpha \tau о \varphi v ́ \lambda \alpha \kappa 1 ~ \kappa \alpha i ̀ ~ \sigma \tau \rho \alpha \tau \eta \gamma \tilde{\varphi}$

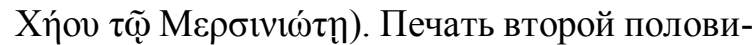
ны XI в., из собрания Государственного Эрмитажа [5, с. 188, № 287].

3. Иоанн Аристин, вестарх и стратиг Хи-

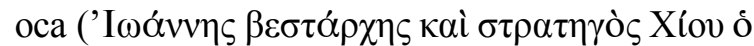

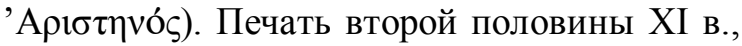
из собрания Государственного Эрмитажа [1, с. 181 , табл. 70 , № 10].

4. Михаил Маврики, вест и стратиг Хиоса

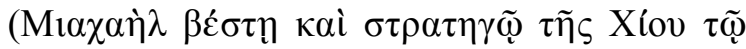

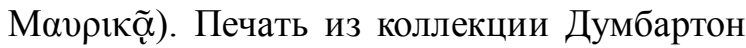
Окс, датируется 1060-1065 гг. [9, p. 125, no. 41.6].

Таким образом, на основании анализа письменных и сфрагистических источников выявлено пять стратигов Хиоса. К сожалению, cursus honorum большинства этих военачальников не может быть установлен. Исключе-

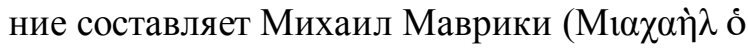

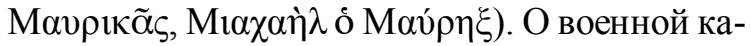
рьере этого уроженца Ираклии Понтийской писал Никифор Вриенний: «был он из простолюдинов, но доблестный и хорошо знакомый с плаванием по морю... императоры считали его человеком полезным и удостаивали больших почестей. На службе Маврики нажил большое богатство, имел множество рабов, служивших ему как воины» [21, p. 197.17-199.3]. В 60-80-е гг. XI в. Михаил Маврики занимал должности стратига Хиоса, катепана Диррахия, дуки Вукеллария и дуки Аниохии. При Алексее Комнине он получил титул куропалата и успешно воевал против норманнов Роберта Гюискара [8, p. 124.39-47; 29, S. 169-171].

Последний раз стратиг Хиоса упоминается в хрисовуле Никифора Вотаниата (10781081), который датирован июнем 1079 года. В этом документе Никифор III подтвердил привилегии Нового монастыря (Nź $\alpha$ Moví) на Хиосе, полученные от предыдущих императоров. Помимо прочего, хрисовул содержит перечень должностных лиц военной и гражданской администрации, которым был запрещен доступ на монастырские земли: «Стратигам Хиоса и подчиненным им таксиархам, турмархам, мерархам, хартулариям дрома и

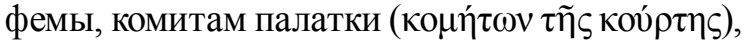
доместикам фемы, друнгарокомитам, протокентархам императорских крепостей, кастрофилакам, кастроктистам (

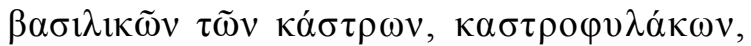
$\kappa \alpha \sigma \tau \rho о \kappa \tau \imath \sigma \tau \tilde{\omega} v) »[6$, p. 9]. Следует отметить, что для императорских хрисовулов ХІ в. упоминание трех последних должностей является уникальным. Протокентарх и кастрофилак командовали гарнизонами крепостей, а кастроктист отвечал за ремонт оборонительных сооружений [24, p. 281-282].

Перечисление в тексте хрисовула армейских командиров, связанных с гарнизонами крепостей, указывает, что военные силы фемы Хиос состояли прежде всего из регулярных контингентов. Подтверждением этому является также упоминание в легендах печатей стратигов Хиоса Льва Карики и Варды Мерсиниота должности $\tau \alpha \gamma \mu \alpha \tau о \varphi v ́ \lambda \alpha \xi$. Этот пост 
появился в византийской армии во второй половине Х в., когда было сформировано значительное число новых регулярных подразделений - кавалерийских тагм и пехотных таксиархий. Первоначально тагматофилаки командовали этими отрядами, входившими в состав полевых армий Востока и Запада. Отметим также, что в источниках данная должность всегда упоминается без названия тагмы и крайне редко с указанием места службы военачальника. В правление Василия II некоторые тагмы были подчинены стратигам малых фем. В период военных действий они были основной боевой силой фемного войска, а в мирное время составляли гарнизоны находящихся на территории провинции крепостей. Не исключено, что некоторые провинциальные тагмы включали в свой состав как кавалерийские, так и пехотные подразделения. Кроме того, с середины XI в. в тагмах начали служить иностранные наемники [3, с. 22-23; 7 , p. 150 , no. 4; 29, S. 219].

Учитывая достаточно большую площадь острова (ок. $840 \mathrm{kм}^{2}$ ) и протяженность его береговой линии (более 200 км), для надежной обороны требовалось несколько укрепленных пунктов. Судя по отрывочным сведениям письменных источников X-XIV вв., а также археологическим, эпиграфическим и сфрагистическим данным, на Хиосе было несколько крепостей, в которых войска размещались на постоянной основе. Прежде всего, это

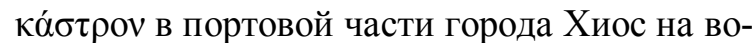
сточном побережье острова. Кроме того, известно о существовании небольших укреплений южнее города, в районе Карфас (Карфа́s), на северо-восточном берегу - Кардамила

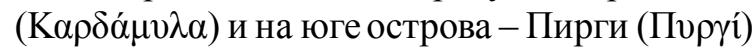
[16, S. 186, 188, 270]. Можно предположить, что размещенная на Хиосе тагма была разделена на несколько частей, которые находились в этих крепостях.

О северо-западной части острова следует упомянуть отдельно. По всей видимости, в византийское время этот район не был связан с главным поселением сухопутными коммуникациями, связь между ними поддерживалась по морю. Здесь располагалась кре-

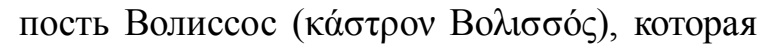
защищала расположенную в 2 км к юго-западу корабельную стоянку Лимния $(\Lambda \eta \mu \nu i \alpha ́)$.
Сохранившиеся до нашего времени оборонительные сооружения Волиссоса были возведены в XI веке. Крепость имеет трапециевидную форму с шестью круглыми башнями. С северного, восточного и западного направлений она неприступна. Доступ в крепость возможен только с южной стороны, где расположены единственные ворота. Кастрон господствует над плодородной долиной, отсюда хорошо просматривается западное побережье острова, от гавани Лимния до порта Литхи

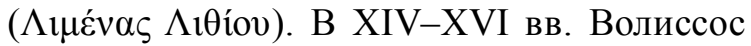
принадлежал генуэзцам и являлся административным центром северо-западной части Хиоса. В генуэзских документах эта «сильная крепость на высокой горе» обозначается как Volisso или Ulisso [16, S. 138-139].

С крепостью Волиссос связан уникальный сфрагистический памятник Х в., который хранится в собрании Думбартон Окс. На лицевой стороне печати помещено изображение Иоанна Крестителя. На оборотной стороне надпись из семи строк: «Господи, помоги своему рабу Нафанаилу, дуке Волисоса» (Кúрıє,

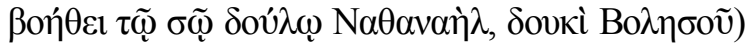
[9, p. 137, no. 46.1].

Судя по легенде, владелец печати являлся дукой, причем это его должность, а не ти-

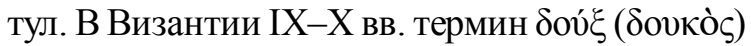
мог обозначать либо командира отряда регулярных войск, либо главу небольшого административного округа, подчиненного стратигу фемы [22, р. 342, 349]. В данном случае более обоснованным, по нашему мнению, является второй вариант значения термина. Издатели печати предположили, что Нафанаил мог быть предводителем этнической группы, переселившейся на Хиос с Балканского полуострова. Крайне редкое библейское имя владельца буллы может указывать на то, что его соплеменники недавно приняли христианство. Если это предположение верно, то дука Нафанаил получил свое имя в честь ветхозаветного Нетанеля, сына Цуара, главы колена Иссахарова во время странствования евреев в пустыне во времена Моисея (Чис. 1:8).

Завершая характеристику структур управления фемы Хиос в XI в., следует упомянуть о должностных лицах гражданской администрации. Отметим, что они известны только по данным сфрагистики. 


\section{ВОЙНА И ВИЗАНТИЙСКОЕ ОБЩЕСТВО}

Наиболее высокое место в фемной чиновной иерархии занимали судьи. В коллекции Афинского нумизматического музея хранится печать середины XI в., которая принадлежала Льву, вестарху, судье вила и Хио-

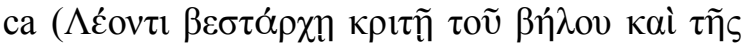
Хíov) $[17$, б. 37, № 38]. Владелец печати состоял в столичной судебной коллегии и одновременно исполнял судебные функции на Хиосе.

Два моливдовула принадлежали должностным лицам налогового ведомства. Первый из них датируется $\mathrm{X}$ в., его владельцем являлся Никита, императорский кандидат и диикит

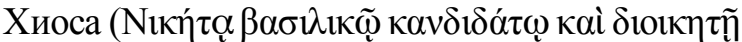
$\tau \tilde{\eta}_{\varsigma}$ Xíov) [17, б. 38, № 39]. Второй, принадлежавший Михаилу, диикиту Хиоса (Мıфа̀े $\lambda$ $\delta$ เокп $\tau \tilde{\eta}$ Xíov), был опубликован Г. Шлюмберже. Издатель не датировал моливдовул, но по сфрагистическому типу он может быть отнесен к XI в. [28, p. 196, no. 1].

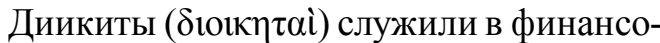
вом ведомстве и занимались сбором налогов. Первоначально они приезжали в провинции из Константинополя. С середины X в. в фемах появляются диикиты, приписанные к местной администрации на постоянной основе. Вместо платы за службу эти чиновники получали синетейю (бvvท́ $\theta \varepsilon 1 \alpha)$ - определенную часть от собранных ими денежных сумм. Известно также, что диикитами часто становились вышедшие в отставку стратиоты и младшие командиры регулярных тагм, которым по рангу не полагались официальные придворные титулы [4, с. 282].

В собрании Думбартон Окс хранятся две печати, принадлежавшие ориариям Хиоса. Печать Михаила, императорского клирика и

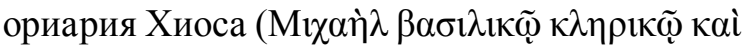

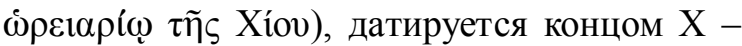
началом XI века. На лицевой стороне буллы помещено редкое для византийской сфрагистики изображение св. Фомы [9, р. 125, no. 41.5]. Вторая печать принадлежала Лазарю, кувуклесию и ориарию Хиоса $(\Lambda \alpha \zeta \alpha ́ \alpha \omega$

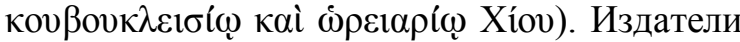
датировали ее первой половиной ХІ в. [9, р. 124, no. 41.4].

Судя по титулатуре, оба ориария принадлежали к духовенству. Однако императорский клирик Михаил служил в государственном финансовом ведомстве, а кувуклисий Лазарь - в церковном. Известно, что функции ориария

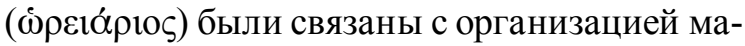
териальных поставок для императорского двора, армии, церкви, благотворительных учреждений. В некоторых провинциях население вместо выплаты налогов в денежной форме несло натуральные повинности. Продовольствие, редкие сорта древесины, сырье для императорских ремесленных мастерских и пр. поступали в специальные хранилища, работой которых руководили ориарии [4, с. 282]. Можно предположить, что деятельность этих должностных лиц на Хиосе была связана с заготовкой смолы мастичного дерева.

Военно-административная система, созданная в Византии при императорах Никифоре Фоке, Иоанне Цимисхии и Василии II, существовала до 60-70-х гг. ХІ века. После поражения византийской армии при Манцикерте и последовавшей за этим борьбой за власть между Дуками и Романом IV Диогеном деградация фемной системы стала необратимой. В правление Михаила VII Дуки и Никифора III Вотаниата сельджуки захватили значительную часть Малой Азии, включая приморские районы фемы Фракисий. Один из крупных турецких отрядов обосновался в Смирне (совр. İzmir, Измир). В 1090 г. эмир Смирны Чакан

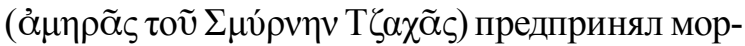
скую экспедицию, в ходе которой ему удалось

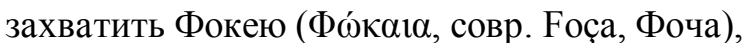
Митилини, Самос и Хиос. Алексей I Комнин отправил против эмира Смирны крупные военные силы. В «Алексиаде» Анны Комниной содержится подробный рассказ об осаде крепости Хиос императорским флотом [8, p. 222226]. В целом, борьба с Чаканом и его наследниками продолжалась до 1098 года. Несмотря на то, что Византии удалось восстановить контроль над бывшими владениями эмира Смирны, фемные структуры в данном регионе были ликвидированы [7, p. 184-186]. Утверждение Э. Маламут о том, что в 1160-е гг. на Хиосе существовала административная

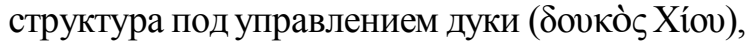
не подтверждается свидетельствами византийских источников [20, p. 326]. Известны только имена дук Хиоса конца XIII - первой половины

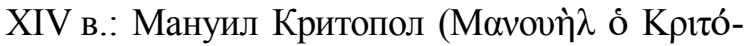

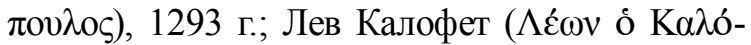

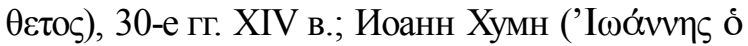


Хои̃ 30954]. В данное время Византия вела борьбу с Генуей за власть над Хиосом. Однако империя потерпела поражение и остров на двести лет перешел под власть Республики св. Георгия.

Подводя итоги, отметим, что византийская фема Хиос существовала около ста лет. Она стала одной из последних военно-административных единиц, созданных в Византии периода «фемного строя». По времени ее появление совпадает с организацией Василием II ряда малых фем на Балканах и на островах Эгейского моря. Основой военных сил этих фем являлись регулярные войска. На протяжении большей части XI в. Хиос, Самос, фема Кикладских островов образовывали передовую линию обороны на дальних подступах к Константинополю.

\section{ПРИМЕЧАНИЕ}

1 Статья подготовлена при финансовой поддержке РГНФ, проект № 16-31-00027 («Византийская армия в VIII-XI вв.: организационные структуры, командный состав, повседневная жизнь»).

Article was prepared with the financial support of the «Russian Foundation for Humanities», the project No. 16-31-00027 ("The byzantine army in VIII - XI centuries: organizational structure, command of the armed forces, everyday life").

\section{СПИСОК ЛИТЕРАТУРЫ}

1. Лихачев, Н. П. Моливдовулы греческого Востока / Н. П. Лихачев ; сост. и авт. коммент. В. С. Шандровская. - М. : Наука, 1991.-359 с.

2. Мохов, А. С. Военные преобразования в Византийской империи во второй половине $\mathrm{X}$ начале XI в. / А. С. Мохов // Известия Уральского государственного университета. Сер. 2, Гуманитарные науки. - 2004. - № 31. - С. 14-33.

3. Мохов, А. С. Микроструктуры византийской военно-административной системы в X-XI вв.: фема Сервия / А. С. Мохов // Известия Уральского государственного университета. Сер. 2, Гуманитарные науки. -2010 . - № 79. - С. 19-30.

4. Мохов, А. С. Византийская фамилия Спондилов в XI-XIII вв. / А. С. Мохов // Античная древность и средние века. - 2011. - Вып. 40. - С. 269-287.

5. Шандровская, В. С. Сфрагистика / В. С. Шандровская // Коллекция Музея РАИК в Эрмитаже : ка- талог выставки / науч. ред. В. С. Шандровская. -СПб. : Государственный Эрмитаж, 1994. - С. 176-202.

6. Acta et diplomata graeca medii aevi sacra et profana / ed. Fr. Miklosich, I. Müller. - Wien : C. Gerold, 1887. - Vol. 5. $-481 \mathrm{p}$.

7. Ahrweiler, H. Byzance et la mer. La marine de guerre, la politique et les institutions maritimes de Byzance aux VIIe - XVe siècles / H. Ahrweiler. - Paris : Presses univ. de France, 1966. -506 p.

8. Annae Comnenae Alexias / rec. D. R. Reinsch, A. Kambylis, F. Kolovou. - Berlin ; New York : De Gruyter, 2001. - T. 1. -569 p. - (Corpus fontium historiae Byzantinae; vol. 40).

9. Catalogue of Byzantine seals at Dumbarton Oaks and in the Fogg Museum of art / ed. by J. Nesbitt, N. Oikonomides. - Washington, D. C. : Dumbarton Oaks research libr. and coll., 1994. - Vol. 2. - 233 p.

10. Cook, J. M. Old Smyrna, 1948-1951 / J. M. Cook // Annual of the British School at Athens. -1958-1959. - Vol. 53-54. - P. 1-34.

11. Dunn, A. The exploitation and control of woodland and scrubland in the Byzantine world / A. Dunn // Byzantine and Modern Greek studies. 1992. - Vol. 16. - P. 235-298.

12. Eickhoff, E. Seekrieg und Seepolitik zwischen Islam und Abendland. Das Mittelmeer unter byzantinischer und arabischer Hegemonie (650-1040) / E. Eickhoff. - Berlin : De Gruyter, 1966. - 438 S.

13. Excavations in Chios 1952-1955: Byzantine Emporio / M. Ballance, J. Boardman [et al.] // British School of Archaeology at Athens, Suppl. Vol. London : Thames and Hudson, 1989. - № 20.

14. Ioannis Scylitzae Synopsis historiarum / rec. I. Thurn. - Berlin ; New York : De Gruyter, 1973. 579 p. - (Corpus fontium historiae Byzantinae ; vol. 5).

15. Jones, A. H. M. Later Roman Empire, 284-602: A social, economic, and administrative survey /A. H. M. Jones.-Oxford: Blackwell Publ., 1964.-1518 p.

16. Koder, J. Aigaion Pelagos: die nördliche Ägäis / J. Koder. - Wien : Verl. der Österreichischen Akad. der Wiss., 1998. - 351 S. - (Tabula imperii Byzantini ; Bd. 10).

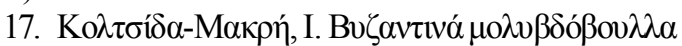

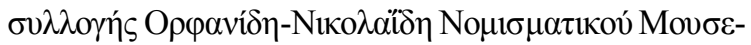

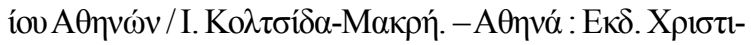

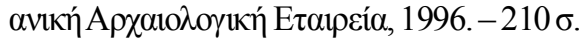

18. Laurent, V. Documents de sigillographie byzantine: La collection C. Orghidan / V. Laurent. Paris : Presses univ. de France, 1952. -339 p.

19. Lawrence, A. W. A skeletal history of byzantine fortification / A. W. Lawrence // Annual of the British School at Athens. - 1983. - Vol. 78. P. 171-227.

20. Malamut, E. Les îles de l'Empire byzantin (VIIIe-XIIe siècles) / E. Malamut. - Paris : Publ. de la Sorbonne, 1988. $-712 \mathrm{p}$. 
21. Nicephori Bryennii historiarum libri quattuor / rec. P. Gautier. - Bruxelles : Publ. Soc. "Byzantion", 1975. - 409 p. - (Corpus fontium historiae Byzantinae ; vol. 9).

22. Oikonomidès, N. Les listes de préséance byzantines des IXe et Xe siècles / N. Oikonomidès. Paris : Centre nat. de la rech. sci., 1972. -403 p.

23. Oikonomides, N. The usual lead seal / N. Oikonomides // Dumbarton Oaks Papers. Washington, D. C. : Dumbarton Oaks research libr. and coll., 1983. - №. 37. - P. 147-157.

24. Oikonomidès, N. Fiscalité et exemption fiscale à Byzance (IXe-XIe s.) / N. Oikonomidès. -Athènes : Fond. nat. de la rech. sci., 1996. -319 p.

25. Prosopographischen Lexikons der Palaiologenzeit / E. Trapp, R. Walther, H.-V. Beyer, [u. a.]. - Wien : Verl. der Österreichischen Akad. der Wiss., 1976-1995. - Fasc. 1-12.

26. Pryor, J.H. The age of the dromonn: the Byzantine navy ca 500-1204 / J. H. Pryor, E. M. Jeffreys. Leiden ; Boston : Brill Publ., 2006. - 754 p.

27. Šandrovskaja, V. S. Byzantinische Bleisiegel der Staatlichen Eremitage mit Familiennamen / V. S. Šandrovskaja, W. Seibt. - Wien : Verl. der Österreichischen Akad. der Wiss., 2005. - 1. Teil. $142 \mathrm{~S}$.

28. Schlumberger, G. Sigillographie de l'Empire byzantin / G. Schlumberger. - Paris : E. Leroux, 1884. $748 \mathrm{p}$.

29. Seibt, W. Die byzantinischen Bleisiegel in Österreich /W. Seibt. - Wien : Verl. der Österreichischen Akad. der Wiss., 1978. - 348 S

30. Zacos, G. Byzantine lead seals / G. Zacos, A. Veglery. - Basel : J. J. Augustin Publ., 1972. Vol. 1. $-1435 \mathrm{p}$

\section{REFERENCES}

1. Likhachev N.P., Shandrovskaya V.S. Molivdovuly grecheskogo Vostoka [Lead Seals of the Greek East]. Moscow, Nauka Publ., 1991. 359 p.

2. Mokhov A.S. Voennye preobrazovaniya $\mathrm{v}$ Vizantiyskoy imperii vo vtoroy polovine $\mathrm{X}$ - nachale XI v. [Military Transformations in the Byzantine Empire in the Second Half of the 10th - Beginning of the 11th Century]. Izvestiya Uralskogo gosudarstvennogo universiteta. Seriya 2, Gumanitarnye nauki, 2004, no. 31, pp. 14-33.

3. Mokhov A.S. Mikrostruktury vizantiyskoy voenno-administrativnoy sistemy $\mathrm{v} X-\mathrm{XI}$ vv.: fema Serviya [Microstructures of the Byzantine MilitaryAdministrative System in the 10th - 11th Centuries: Theme of Servia]. Izvestiya Uralskogo gosudarstvennogo universiteta. Seriya 2, Gumanitarnye nauki, 2010, no. 79, pp. 19-30.
4. Mokhov A.S. Vizantiyskaya familiya Spondilov v XI-XIII vv. [Byzantine Family of Spondyloi in 11 th -12 th Centuries]. Antichnaya drevnost i srednie veka, 2011, iss. 40, pp. 269-287.

5. Shandrovskaya V.S. Sfragistika [Sigillography]. Shandrovskaya V.S., ed. Kollektsiya Muzeya RAIK v Ermitazhe: katalog vystavki [Collection of the Museum of Russian Archaeological Institute in Constantinople in the Hermitage: the Exhibition Catalog]. Saint Petersburg, State Hermitage Museum, 1994, pp. 176-202.

6. Miklosich Fr., Müller, I., eds. Acta et diplomata graeca medii aevi sacra et profana. Vol. 5. Wien, C. Gerold, 1887, vol. 5. 481 p. (in Greek).

7. Ahrweiler H. Byzance et la mer. La marine de guerre, la politique et les institutions maritimes de Byzance aux VIIe - XVe siècles [Byzantium and Sea: the Navy, Politics and Maritime Institutions of Byzantium in the 7 th -15 th Centuries]. Paris, Presses univ. de France, 1966. 506 p. (in French).

8. Reinsch D.R., Kambylis A., Kolovou F., eds. Annae Comnenae Alexias. Vol. 1. Berlin, New York, De Gruyter, 2001. 569 p. (Corpus fontium historiae Byzantinae, vol. 40). (in Greek).

9. Nesbitt J., Oikonomides N., eds. Catalogue of Byzantine seals at Dumbarton Oaks and in the Fogg Museum of art. Vol. 2. Washington, D.C., Dumbarton Oaks research libr. and coll., 1994. 233 p.

10. Cook J.M. Old Smyrna, 1948-1951. Annual of the British School at Athens, 1958-1959, vol. 53-54, pp. 1-34.

11. Dunn A. The Exploitation and Control of Woodland and Scrubland in the Byzantine World. Byzantine and Modern Greek studies, 1992, vol. 16, pp. 235-298.

12. Eickhoff E. Seekrieg und Seepolitik zwischen Islam und Abendland: Das Mittelmeer unter byzantinischer und arabischer Hegemonie (6501040) [Warfare and the Sea Between Islam and the West: the Mediterranean Sea Under Byzantine and Arab Hegemony (650-1040)]. Berlin, De Gruyter. 438 p. (in German).

13. Ballance M., Boardman, J., et al., eds. Excavations in Chios 1952-1955: Byzantine Emporio. British School of Archaeology at Athens, Suppl. Vol. London, Thames and Hudson, 1989, no. 20. 190 p.

14. Thurn I., ed. Ioannis Scylitzae Synopsis historiarum. Berlin; New York, De Gruyter, 1973. 579 p. (Corpus fontium historiae Byzantinae, vol. 5). (in Greek).

15. Jones A.H.M. Later Roman Empire, 284-602: A social, economic, and administrative survey. Oxford, Blackwell Publ. 1964. 1518 p.

16. Koder J. Aigaion Pelagos: die nördliche Ägäis [Aigaion Pelagos: the North Aegean]. Wien, Verl. der Österreichischen Akad. der Wiss., 1998. 351 p. (Tabula imperii Byzantini, vol. 10). (in German).

17. Koltsida-Makrē I. Byzantina molybdobulla: syllogēs Orphanidē-Nikolaidē Nomismatiku Museiu 
Athēnōn [Byzantine Lead Seals Orphanides-Nicolaides Collection in Athens Numismatic Museum]. Athēna, Christianikē Archaiologikē Etaireia, 1996. 210 p. (in Greek).

18. Laurent V. Documents de sigillographie byzantine: La collection C. Orghidan [Byzantine Sigillography Documents: Collection of C. Orghidan]. Paris, Presses univ. de France, 1952. 339 p. (in French).

19. Lawrence A.W. A skeletal history of byzantine fortification. Annual of the British School at Athens, 1983, vol. 78, pp. 171-227.

20. Malamut E. Les îles de l'Empire byzantin (VIIIe-XIIe siècles) [Islands of the Byzantine Empire (8th - 12th Centuries)]. Paris, Publ. de la Sorbonne, 1988. 712 p. (in French).

21. Gautier P., ed. Nicephori Bryennii historiarum libri quattuor. Bruxelles, Publ. Soc. "Byzantion", 1975. 409 p. (Corpus fontium historiae Byzantinae, vol. 9). (in Greek).

22. Oikonomidès N. Les listes de préséance byzantines des IXe et Xe siècles [Byzantine Precedence Lists of the 9th and 10th Centuries]. Paris, Centre nat. de la rech. sci., 1972. 403 p. (in French).

23. Oikonomides N. The usual lead seal. Dumbarton Oaks Papers. Washington, D.C., Dumbarton Oaks research libr. and coll., 1983, no. 37, pp. 147-157.
24. Oikonomidès N. Fiscalité et exemption fiscale à Byzance (IXe-XIe s.) [Taxation and tax exemption in Byzantium ( 9 th -12 th centuries) $]$. Athènes, Fond. nat. de la rech. sci., 1996. 319 p. (in French).

25. Trapp E., Walther R., Beyer H.-V., et al. Prosopographischen Lexikon der Palaiologenzeit [Prosopographic lexicon of the Palaeologus time]. Wien, Verl. der Österreichischen Akad. der Wiss., 19761995, vol. 1-12. (in German).

26. Pryor J.H., Jeffreys E.M. The age of the dromon: the Byzantine navy ca 500-1204. Leiden, Boston, Brill Publ., 2006. 754 p.

27. Šandrovskaja V.S., Seibt W. Byzantinische Bleisiegel der Staatlichen Eremitage mit Familiennamen. Vol. 1 [Byzantine lead seal in the State Hermitage Museum with family name]. Wien, Verl. der Österreichischen Akad. der Wiss., 2005, 142 p. (in German).

28. Schlumberger G. Sigillographie de l'Empire byzantin [Sigillography of the Byzantine Empire]. Paris, E. Leroux, 1884. 748 p. (in French).

29. Seibt W. Die byzantinischen Bleisiegel in Österreich. Vol. 1 [Byzantine lead seals in Austria]. Wien, Verl. der Österreichischen Akad. der Wiss., 1978. 348 p. (in German).

30. Zacos G., Veglery A. Byzantine lead seals. Basel, J.J. Augustin Publ., 1972, vol. 1. 1435 p.

\section{Information About the Author}

Anton S. Mokhov, Doctor of Sciences (History), Professor, Department of Ancient and Medieval History, Ural Federal University, Mira St., 19, 620002 Ekaterinburg, Russian Federation, rkb2004@yandex.ru.

\section{Информация об авторе}

Антон Сергеевич Мохов, доктор исторических наук, профессор кафедры истории древнего мира и средних веков, Уральский федеральный университет, ул. Мира, 19, 620002 г. Екатеринбург, Российская Федерация, rkb2004@yandex.ru. 